\title{
The Provision of Carrot Catfish Dumplings Affects the Weight of Elementary School Students with Low Nutritional Status
}

Rosmana Dadang ${ }^{1}$, Munawaroh Silmi Dzakiyyah ${ }^{1}$, Widartika Widartika ${ }^{1}$, Dewi Maryati ${ }^{1}$, Mamat Rahmat ${ }^{1}$, Surmita Surmita $^{1}$, Pusparini Pusparini ${ }^{1}$, Fred Agung ${ }^{1}$, Fuadah Ashri Nurfurqon ${ }^{1}$, Ali Hamzah ${ }^{2}$, Gurid Pramintarto Eko Mulyo ${ }^{1 *}$ (D)

${ }^{1}$ Department of Nutrition, Poltekkes Kemenkes Bandung, Bandung, Indonesia; ${ }^{2}$ Department of Nursing, Poltekkes Kemenkes Bandung, Bandung, Indonesia

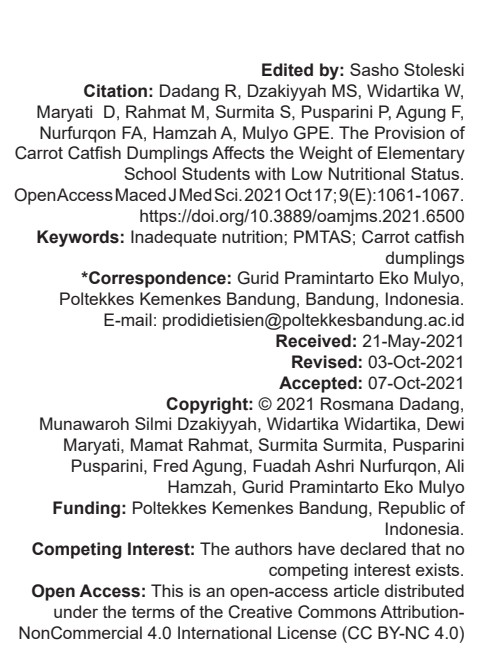

\begin{abstract}
BACKGROUND: A good nutritional status will improve health for average growth and physical development, and intelligence. The prevalence of schoolchildren (5-12 years) with malnutrition status based on brachial fat area is $11.2 \%$, and the number of elementary schoolchildren with malnutrition status in Cibereum village is 107 students. The government has a School Child Supplement Program to meet schoolchildren's dietary needs. It is necessary to have additional food for schoolchildren to improve their nutritional status, especially for students with low nutritional quality.

AIM: The purpose of this study was to determine the effect of carrot catfish dumplings on the bodyweight of elementary school students with poor nutritional status as a form of supplementary food for schoolchildren.

METHODS: Researchers conducted this study in January 2020 at Elementary Schools at the Cibereum Health Center (SDN Cibeureum 5, Cibeureum 7, and Cibereum Mandiri 2) with a sample of 25 people. The research design used is quasi-experimental using one-group pretest-posttest and statistical tests using the Wilcoxon test.

RESULTS: The research test results showed that carrot catfish dumplings affected elementary school students' body weight with low nutritional status.

CONCLUSION: Carrot catfish dumplings can increase students' energy intake and protein intake so that there is an increase in the average body weight of the sample by $0.55 \mathrm{~kg}$. Suggestions for further research to conduct a similar study using a control group as the comparison group.
\end{abstract}

\section{Introduction}

A good nutritional status will improve individual and community health. Good nutritional status is essential for average growth and physical development, and intelligence for infants, children, adolescents, and age groups [1]. The prevalence of schoolchildren (5-12 years) with malnutrition status based on brachial fat area (BFA) is $11.2 \%$ [2]. The number of elementary schoolchildren with malnutrition status in Cibereum village is 107 students [3].

Based on research conducted by Rosita et al. in 2014 concerning the relationship between Nutritional Status and StudentAchievement at the State Elementary School 01 Guguk Malintang, Padangpanjang City, there is a significant relationship between nutritional status and student achievement with $p=0.02$ [4].

According to UNICEF, malnutrition occurs due to comorbidities and inadequate food intake [5]. Many things influence food intake, including refusing to eat, asking for specific food types, eating only a little due to certain factors, namely, diet, eating habits, appetite, family, social trends, mass media, peers, and the influence of drugs [6]. Children's growth and development will be good if their nutritional intake quality and quantity are promising [6].

The government has a schoolchildren's supplementary food program to meet schoolchildren's nutritional needs by providing additional food. The nutritional content of supplemental nutrition for schoolchildren must contain a minimum of 300 calories of energy and $5 \mathrm{~g} \mathrm{[6].}$

Therefore, it is necessary to provide additional food for schoolchildren (PMTAS) to help meet schoolchildren's nutritional needs. The results of the 2013 Tanziha research at SDN Pesanggrahan 2, Pesanggrahan Village, Tegalwaru District, Purwakarta Regency showed a significant effect of supplementary feeding for schoolchildren on changes in nutritional status of schoolchildren (BMI/U) from the proportion of normal dietary status $52.5-92.1 \%(p<0.005)$ [7].

The research conducted by Septi Nora in 2018 stated that there was an effect of providing schoolchildren with additional food on the nutritional 
status and learning achievement of elementary school students in Solok. Students being given an intervention 30 times by providing supplementary food containing an average nutritional value of $335 \mathrm{kcal}$ of energy and $9.6 \mathrm{~g}$ of protein. After the intervention, there was an increase in normal nutritional status from $74.7 \%$ to $84.3 \%$ there was a decrease in moderately wasted cases from $21.4 \%$ to $14.3 \%$ and severely wasted cases from $2.9 \%$ to $1.4 \%$. There is an increase in learning achievement from 76.0 to 77.0. Based on the results of statistical tests, there are differences in the nutritional status of schoolchildren after giving additional food with the acquisition of $p<0.0001$. There was a difference in learning achievement after giving additional food to schoolchildren with the acquisition of $p=0.001$ [8].

One of the favorite forms of supplementary food for schoolchildren is dumplings. The dumplings that we often find in hawker places or other places still do not have many choices in the value of the variety of flavors or the diversity of the raw materials used. Syifa's research (2019) developed local products as a variety of dumplings, namely, carrot catfish dumplings, as an alternative food high in protein, fiber, and Vitamin $A$ for schoolchildren $123.7 \mathrm{kcal}$ of energy and $4.8 \mathrm{~g}$ of protein [9].

Based on the explanation above, this underlies the need for additional food interventions for schoolchildren with malnutrition to improve schoolchildren's nutritional quality. Thus, researchers are interested in conducting research that aims to determine the effect of giving carrot catfish dumplings on the weight gain of schoolchildren under nutritional status in one of the working areas of the Public Health Center in Cibereum Village, Cimahi City.

\section{Methods}

The research design used was quasiexperiment using one-group pretest-posttest. This study aims to determine the effect of the intervention of additional feeding in the form of carrot catfish dumplings on body weight. This study design compared body weight before and after the intervention - body weight as the dependent variable and the provision of carrot catfish dumplings as the independent variable. The study involved three elementary schools (Cibereum 5, Cibereum 7, and Cibereum Mandiri 2 Elementary Schools) in the Cibereum Public Health Center's working area South Cimahi District, Cimahi City. The selection of primary schools used purposive based on elementary students with poor nutritional status.

This study's sample population was elementary school students in the Cibereum Puskesmas working area who have a malnutrition status category. The formula calculates the sample size:

$$
\begin{gathered}
n=\left[\frac{Z \alpha+Z \beta \cdot S d}{d^{2}}\right]^{2} \\
{ }^{*} Z \alpha=1.96 \\
Z \beta=0.84 \\
S d=0.9 \\
d 2=0.52
\end{gathered}
$$

Based on these calculations, the minimum number of samples required is 24 people, with the anticipation of the possibility of a sample dropping out of three people (10\% of the sample). Sampling using purposive sampling. The criteria determined are elementary school students Grade 1-Grade 5 who are active as elementary school students in the working area of the Cibereum Health Center (SDN Cibereum 5, Cibereum 7, and Cibereum Mandiri 2). In addition, samples must have a Z score BFA - 3SD to $<-2 S D$ and have homeroom and parent permission to attend the entire course and not have a fish allergy. In comparison, the exclusion criteria were not willing to be involved in the study. The dropout criteria in this study were students who did not follow the research process as a whole because they were unable to attend and were seriously ill at the time of the survey.

The Ethical Committee has approved this study with the number: 10/KEPK/PE///2020.

Catfish dumplings were given to the research sample once a day within 2 weeks of effective school days (12 days). Researchers gave one serving of carrot catfish dumplings containing five dumplings (112.5 g) with an energy content of $309.25 \mathrm{kcal}(26.2 \%$ of the sample-based daily energy adequacy) on the average recommended dietary allowance (RDA) for children $7-12$ years) and $12 \mathrm{~g}$ of protein (17.41\% of the daily protein adequacy of the sample based on the average RDA for children aged 7-12 years).

The data collected are in the form of secondary data and primary data. Secondary data include sample characteristics, including name, gender, and age. Meanwhile, preliminary data consist of a history of fish allergy samples based on interviews, student food intake based on $1 \times 24 \mathrm{~h}$ food recall interviews (twice before the intervention and twice during the intervention), and anthropometric data (body weight before and height) obtained from direct measurement results. The researcher measured the sample's weight before and after the intervention (intervention carried out for 12 days). The results of research by Ratnayani et al. (2010) that there was an increase in body weight of 0.86 in food products with a mixture of catfish (300 $\mathrm{kcal} 10 \mathrm{~g}$ of protein) given for 3 months with a total of 36 times in 3 months (12x/month) [10]. Measurements using a digital scale with an accuracy of $0.1 \mathrm{~kg}$. 
Data processing carried out using NutriSurvey and SPSS Statistic 20 applications. Sample characteristic data presented in the form of a frequency distribution table then analyzed descriptively.

Before and after the intervention, the weight measurement results analyzed using the normality test with the Shapiro-Wilk test. The bivariate test carried out using the Wilcoxon test because the distribution of weight variable data was not normally distributed $(p \leq 0.005)$.

\section{Results}

The sample in this study was 25 elementary school students with malnutrition status in the Cibereum Health Center working area.

Table 1 shows that the youngest sample age is 7 years. The oldest age is 11 years. The age in the study sample ranged from 7 to 11 years and this is because the model is at Grade 1-Grade 5 primary school level so that the age distribution varies. Most of the sample is male with 14 people, and for the female gender, there are 11 people.

Table 1: Frequency distribution of sample characteristics

\begin{tabular}{lll}
\hline Characteristics & $\mathrm{n}$ & $\%$ \\
\hline Gender & 14 & 56.0 \\
$\quad$ Man & 11 & 44.0 \\
$\quad$ Women & & \\
Age & 2 & 8.0 \\
7 years & 7 & 28.0 \\
8 years & 5 & 20.0 \\
9 years & 4 & 16.0 \\
10 years & 5 & 28.0 \\
11 years old & 25 & 100.0 \\
Total &
\end{tabular}

Based on the 1999 Ministry of Health, the level of energy and protein adequacy categorized as severe deficit ( $<60 \%$ RDA), moderate deficit (60-69\% RDA), mild deficit (70-79\% RDA), good (80-120\% RDA), and more ( $\geq 120 \%$ RDA) [11].

Based on Table 2, before the intervention, no samples had a good level of energy intake. The level of adequacy of energy intake during the severe deficit intervention decreased to $40.0 \%$ from $72.0 \%$, and the level of good energy intake increased from

Table 2: Levels of energy intake and protein intake

\begin{tabular}{|c|c|c|c|c|}
\hline \multirow[t]{2}{*}{ Variable } & \multicolumn{2}{|c|}{ Before the intervention } & \multicolumn{2}{|c|}{ During the intervention } \\
\hline & $\mathrm{n}$ & $\%$ & $\mathrm{n}$ & $\%$ \\
\hline \multicolumn{5}{|l|}{ Energy intake } \\
\hline Severe deficit & 18 & 72.0 & 10 & 40.0 \\
\hline $\begin{array}{l}\text { Moderate } \\
\text { deficit }\end{array}$ & 6 & 24.0 & 4 & 16.0 \\
\hline Mild deficit & 1 & 4.0 & 4 & 16.0 \\
\hline $\begin{array}{l}\text { Good } \\
\text { Protein intake }\end{array}$ & 0 & 0.0 & 7 & 28.0 \\
\hline Severe deficit & 12 & 48.0 & 4 & 16.0 \\
\hline $\begin{array}{l}\text { Moderate } \\
\text { deficit }\end{array}$ & 7 & 28.0 & 2 & 8.0 \\
\hline Mild deficit & 3 & 12.0 & 4 & 16.0 \\
\hline Good & 3 & 12.0 & 11 & 44.0 \\
\hline More & 0 & 0.0 & 4 & 16.0 \\
\hline Total & 25 & 100.0 & 25 & 100.0 \\
\hline
\end{tabular}

$0 \%$ to $7 \%$. Likewise, at the level of adequacy of protein intake, there was a decrease in protein intake with a severe deficit from $48.0 \%$ to $16.0 \%$. There is an increase in the adequacy of good protein intake to $44.0 \%$ from $12.0 \%$.

Based on Table 3, the contribution of energy and protein for carrot catfish dumpling in one serving to students' nutritional adequacy is $17.41 \%$.

Table 3: Average energy intake and average protein intake and contribution of carrot catfish Siomay on protein-energy adequacy and total intake

\begin{tabular}{lll}
\hline Variable & Energy (kcal) & Protein (g) \\
\hline Average adequacy of students a day & 1776.00 & 45.8 \\
Average total student intake the day before the intervention & 1002.25 & 30.37 \\
Mean total daily intake of students at the time of intervention & 1372.23 & 43.85 \\
Intake of carrot catfish dumplings intervention & 309.25 & 11.00 \\
Contribution of carrot catfish dumplings to nutritional & 17.41 & 24.02 \\
adequacy (\%) & & \\
Contribution of carrot catfish dumplings to total intake (\%) & 22.54 & 25.09 \\
\hline
\end{tabular}

The gift of energy and protein of carrot catfish dumplings to the students' daily total consumption was $22.54 \%$ and $25.09 \%$, respectively.

Table 4 shows an increase in the average intake of energy and protein, with the difference in energy intake before and after the intervention is 369.98 $\mathrm{kcal}$. The difference in protein intake before and after is $13.48 \mathrm{~g}$.

Table 4: The difference in average protein-energy intake and average body weight

\begin{tabular}{lll}
\hline Variable & Mean & SD \\
\hline Energy intake & 1002.25 & \\
$\quad$ Before the intervention & 1372.23 & 255.91 \\
$\quad$ During the intervention & & 272.19 \\
Protein intake & 30.37 & 8.08 \\
$\quad$ Before the intervention & 44.33 & 8.91 \\
$\quad$ During the intervention & & \\
Weight & 22.86 & 3.66 \\
$\quad$ Before the intervention & 23.41 & 3.81 \\
$\quad$ After the intervention & & \\
\hline
\end{tabular}

Before the intervention, the mean body weight was $22.86 \mathrm{~kg}$, and the mean body weight after the intervention was $23.41 \mathrm{~kg}$. Therefore, based on the average body weight, it can be seen that there is an increase in body weight of $0.55 \mathrm{~kg}$.

The research sample consisted of 25 people, so the normality test used was the Shapiro-Wilk. Based on Table 5, the results of the normality test for "Weight Before Intervention" obtained $p=0.011$, and the normality test results for "Body Weight After Intervention" received $p=0.021$, which means that the two distribution variables are not normal. The bivariate carried out on the bodyweight of the study sample was the Wilcoxon test.

Table 5: Data normality test

\begin{tabular}{llll}
\hline Weight & Normality test & p-value & Result \\
\hline Before the intervention & Shapiro-Wilk & 0.011 & Abnormal \\
After the intervention & & 0.021 & Abnormal \\
\hline
\end{tabular}

The statistical test used for bivariate analysis is the Wilcoxon test. The test results obtained are $p=0.000(p<0.000)$ so that the null hypothesis rejected and the alternative idea is accepted. This research's alternative theory is a relationship between 
Table 6: Effect of intervention on weight gain

\begin{tabular}{lllllll}
\hline Weight & Bivariate test & $\mathrm{p}$-value & $\mathrm{Z}$ & Negative ranks & Positive ranks & Ties \\
\hline Before the & Wilcoxon test & 0.000 & -4.296 & 0 & 24 & 1 \\
intervention & & & & & & \\
After & & & & & & \\
intervention & & & & & \\
\hline
\end{tabular}

carrot catfish dumplings and the sample's body weight.

Table 6 shows relationship of carrot catfish dumplings to body weight has a significant relationship with a positive effect. In addition, an increase in the nutritional intake of the sample compared to the nutritional information of the research sample before the intervention of giving catfish carrot dumplings supported these results.

Based on Figure 1, it shows that the number of research samples was 25 people and there was an increase in body weight before and after the intervention giving carrot catfish dumplings for 12 effective school days.

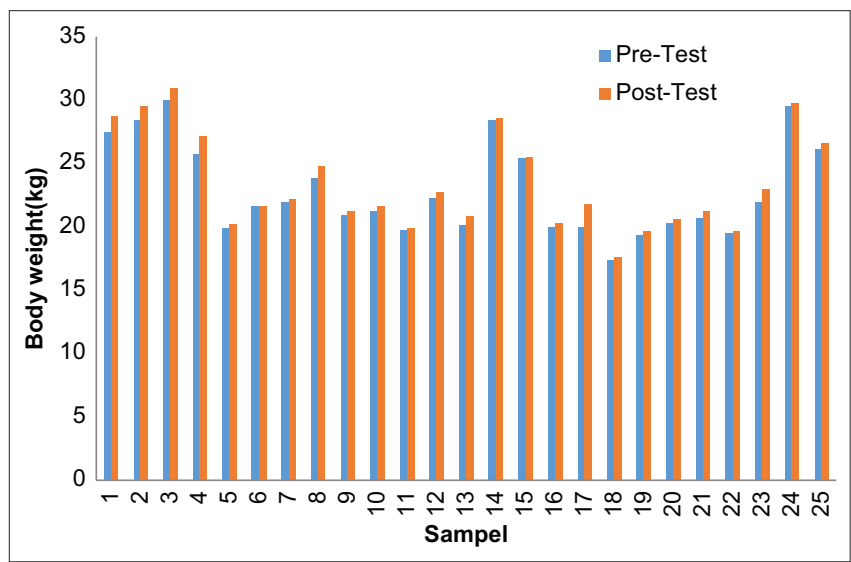

Figure 1: Increase in sample weight before and after the intervention

\section{Discussion}

Based on the sex of the research sample, the study consisted of $14(56.0 \%)$ men and $11(44.0 \%)$ women. The sample selection was not gendered specific. Based on Vita 's research, boys are more malnourished than girls [12]. It is the same as the research of Lubiz (2012) that the malnutrition status was 18 people $(75.0 \%)$ while the malnutrition status was 6 people $(25.0 \%)$ [13]. A person's nutritional status is a balance between intake and dietary needs. Basal metabolic rate (BMR) and physical activity, where BMR is closely related to lean body mass, are met with the body's inputs [14]. In this study, the most excellent malnutrition status was males because boys had higher physical activity and greater lean body mass than girls, which affected metabolism and caused insufficient nutrients, causing malnutrition. Based on Nurapriyanti research $(p=0.916)$, there is no relationship between gender and nutritional status and the same thing as Rahmi's research (2017) ( $p=0.953)$ [15], [16]. The sample in this study is in the age range of 7-11 years, because the model used is Grade 1-Grade 5 elementary school students. According to Gunners and Gunarsa (2010), elementary school children are children aged 6-12 years, have physical abilities that are tougher, active and independent than adults. Many experts consider this period as a period of the calm or latent period. Where what happened in the past will continue for the future [17].

The research sample was $8.0 \% 7$ years old, $28.0 \% 8$ years old, $20.0 \% 9$ years old, $16.0 \% 10$-yearold respondents, and $28.0 \% 11$-year-old sample. Based on these data, it shows that the research sample, which is elementary school students with the most nutritional status, is at the age of $8-9$ years $(48 \%)$, this is in line with the research Vita that 9 -year-old children have many nutritional problems, including nutrition, poor nutrition, lack of food, and overnutrition [12]. Yunita and Tuti's research (2016) shows that the 6-9 years age group is the largest age group with malnutrition. Children aged 6-9 years have started to be affected by the outside environment and have activities outside the home. The incidence of malnutrition status at the age of $10-11$ years (44\%) is different from the results of Yunita and Suyanto study of Dian and Indah that the most underweight nutritional status is at the age of 10-13 years [18], [19]. Based on this theory, there is a transition period between 10 and 19 years, and there is an acceleration of growth [20]. Therefore, the sample is children aged 10-19 years. Weight gain in this age range is not significant. Nutritional status is directly affected by nutrient intake. Nutritional intake measured in this study is energy intake and protein intake. The sample's energy intake and protein intake were obtained based on the $1 \times 24 \mathrm{~h}$ recall results, carried out twice before the intervention and twice during the intervention.

Growth, metabolism in the use of foodstuffs, and physical activity can occur due to energy intake. Lack of energy intake will cause malnutrition. The number of levels of sound energy intake in the sample before the intervention was $0 \%$. It could be one of the causes of the lack of nutritional status in the model. It is in line with Yulni et al.'s (2013) 's research that there is a relationship between energy intake and schoolchildren's nutritional status [21]. Likewise, in Bertalina's (2013) study that there is a relationship between energy intake and nutritional status of schoolaged children (6-12 years), the results of Qomariyah's (2018) study with $p=0.000$, there is also a relationship between energy intake and nutritional status [24], [26].

In addition to energy intake, measurement of protein intake in the sample is based on recall $1 \times 24 \mathrm{~h}$ twice before the intervention and twice during the intervention. Based on the study results, the difference between the increase in the average energy intake before and during the intervention (403.77 kcal) and the 
energy contribution of carrot catfish dumplings (309.25 $\mathrm{kcal})$ is $94.52 \mathrm{kcal}$. Many factors outside the variables studied by researchers affect these results, such as increasing nutritional knowledge, appetite, and food security. Before the intervention, $48.0 \%$ of the sample had a protein intake deficit and $28.0 \%$ of the sample had a low protein intake. With deficit protein intake and models with insufficient protein intake at the intervention time, the percentage reduced to $16.0 \%$ and $8.0 \%$ [24].

The samples with moderate and reasonable protein intake before the intervention were $12.0 \%$ and $3.0 \%$, respectively. When the intervention took place, there was an increase in the sample proportion of moderate protein intake and good protein intake by $16.0 \%$ and $44.0 \%$, respectively. The increase in the proportion of samples with reasonable and good protein intake levels increased intake at intervention compared to pre-intervention protein intake. The difference in the average difference in protein intake before the intervention and at the time of intervention was $13.48 \mathrm{~g}$. It is in line with Salawati and Nurjannah (2014) research with sample children with ARI with undernutrition and overnutrition. There is a significant difference between body weight before and after giving protein intake to Salawati and Nurjannah [25]. Sari's research (2018) shows a relationship between protein intake and elementary schoolchildren's nutritional status [26]. The discussion contains the meaning of the results and comparisons with the theory and similar research results.

The intervention was carrot catfish dumplings as additional food for schoolchildren (MTAS) with an energy content of $309.25 \mathrm{kcal}$ and $11 \mathrm{~g}$ of protein. PMTAS by standards (minimum energy $300 \mathrm{kcal}$ and minimum protein $5 \mathrm{~g}$ ) predictably affect good food consumption to achieve goals, including increasing student body weight, rising student nutritional status, improving nutritional intake, and improving physical endurance [27].

Giving carrot catfish dumplings increase the hope of being able to gain weight for elementary school students. The sample's body weight measurement in this study used a digital scale measuring instrument with an accuracy of $0.1 \mathrm{~kg}$. The intervention duration was given for 2 weeks of effective school days (12 days) with one portion of it each day. The researcher carried out the final weighing with the same conditions as the initial weighing. The weight measurement results showed an increase in body weight after the intervention of 24 people, and one person did not experience an increase or decrease in body weight. Research samples that do not experience weight gain, seen based on food intake after the intervention, still increased. Still, this weight loss was due to the study sample experiencing fever for 2 days, namely, at the $11^{\text {th }}$ and $12^{\text {th }}$ interventions and on a weighing day after the intervention. However, the model did not complain of severe illness and continued to participate in the study. There was no increase in body weight in one sample, which is in line with the theory that illness incidence can interfere with growth in the body [28]. Based on Tanziha's (2013) research, the inclusion criteria for the study of PMTAS were students who did not experience severe illness. Therefore, the research sample includes students with mild disease [12].

There was an increase in the average body weight after the intervention giving carrot catfish dumplings. Several factors can affect weight gain, including energy intake and protein intake. This study showed an increase in energy intake before the intervention (1002.25 kcal) on energy intake during the intervention $(1372.23 \mathrm{kcal})$, which means that it has a difference of 369.98 kcal. In line with Yulni et al.'s (2013) [21] research, there is a relationship between schoolchildren's energy intake and nutritional status [23].

Bodyweight data tested using Wilcoxon test bivariate analysis because the data distribution was not normal. The test results obtained $p=0.000$ so that Ho rejected and the alternative hypothesis is accepted. This research's alternative hypothesis is a relationship between carrot catfish dumplings and the sample's body weight. The relationship of giving carrot catfish dumplings to body weight has a significant relationship with a positive effect. It is in line with the research conducted by Syarfaini et al. (2016) that there is an effect of giving snakehead fish tempeh nuggets on the bodyweight of the case group with $p=0.000$, which is more small from the alpha value. Based on Oktaviani's research (2016), the results of the weight difference test before and after giving PMT showed a significant difference $(p=0.003)$ [29], [30]. The results of this study are also in line with the results of research by IEP et al., Iskandar (2017), and Tanziha et al. The results of this study support a change in the nutritional status of the sample for the better after the intervention of giving additional food 42 times [6], [31], [32].

Based on Susilowati's research, there is a relationship between nutritional status before and after giving additional food. The results of Titi's research show that there are differences in the nutritional status of students before and after giving additional food while in the Kalibening subdistrict, with a sample of 340 students [33], [34].

Several factors affect weight gain, including energy intake consumed. Energy intake comes from consuming foods containing carbohydrates, proteins, and fats. Carbohydrates, proteins, and fats are macronutrients that act as energy sources in the body. When energy intake is by the needs, the malnourished students will gain weight so that their nutritional status will be good. It is in line with Qamariyah's and Nindya research that there is a relationship between energy intake and nutritional status [26]. 
These carrot catfish dumplings have a protein content of $11 \mathrm{~g}$. Based on Hikmawati et al. research, catfish dumplings' protein content has a higher protein content than the usual dumplings [35]. The results of research by Ratnayani et al. (2009) showed that there was an increase in body weight of 0.86 in catfish mixed foodstuff products $(300 \mathrm{kcal}$ $10 \mathrm{~g}$ of protein) given for 3 months (August-October) with a total of 36 times in 3 months (12x/month) [36]. Protein functions for growth, making hormones and enzymes that are important for body metabolism. If the body is deficient in protein, it will cause the body to be susceptible to infection, which is one factor that hinders the intake from decreasing to cause weight loss. If it lasts long, it will decrease nutritional status and vice versa; if protein intake is by the needs, then weight growth is not disturbed, and nutritional status will be good [37].

Protein intake in the body will undergo a deaminase process, separating amino groups from amino acids, which causes nitrogen to be released, and acetyl Co-A formation occurs. Acetyl Co-A formed will undergo a process of fat breakdown or lipolysis so that it turns into triglycerides [38]. Based on this study's results, the average protein intake consumed by the sample at the time of the carrot catfish dumplings intervention increased by $13.44 \mathrm{~g}$ compared to before the intervention. According to Parinduri and Safitri research (2018), there is a relationship between protein intake and nutritional status [23]. In line with Atika's (2015) research, there is a relationship between protein intake and nutritional status [39].

Factors other than the influence of intake are genetics, psychological knowledge, hormones, diet, and culture [40], [41], [42]. Bodyweight is one indicator of determining the value of nutritional status. The nutritional status is also influenced by the knowledge related to the nutrition they have, based on Hartono's research (2016) that there is a relationship between knowledge and nutritional status [43]. In this study, before the intervention giving carrot catfish dumplings, the researchers conducted nutritional counseling on balanced nutrition and healthy snacks as an introduction before the intervention. It can affect the increase in the sample's nutritional knowledge, increasing knowledge, even the sample's attitude to eating better.

\section{Conclusion}

The research shows that carrot catfish dumplings can increase students' energy intake and protein intake so that there is an increase in the average body weight of the sample by $0.55 \mathrm{~kg}$.

\section{Suggestion}

It is necessary to do further research on giving carrot catfish dumplings on body weight for a longer time. There is a control group as a comparison group to obtain maximum results.

\section{Acknowledgments}

The researcher would like to thank Cibereum Public Health Center, Principal of Cibereum 5 , Cibereum 7, Cibereum Mandiri 2 Elementary Schools, and parents of research samples.

\section{References}

1. Pari HM, Wiyono S, Harjatmo TP. Nutritional Status Assessment Teaching Materials. Jakarta: Indonesian Ministry of Health; 2017.

2. Research and Development Agency for Health Ministry of Health of the Republic of Indonesia. National health survey. Science. 2013;127(3309):1275-9.

3. Cimahi DK. Data on Nutritional Status Selection for Elementary School Students in Cimahi City Health Office; 2018.

4. Sa'adah $\mathrm{RH}$, Rahmatina B, Susila S. The relationship between nutritional status and learning achievement of state elementary school students 01 guguk malintang Padangpanjang city. J Kesehatan Andalas. 2014;3(3):460-5. https://doi.org/10.25077/ jka.v3i3.176

5. Sudjatmoko $\mathrm{S}$. Eating problems in children. damianus $\mathrm{J}$ Med. 2011;10(1):36-41.

6. Yulia C. Revitalization of supplementary feeding and integration of nutrition education based on local wisdom in schools as an effort to improve nutrition for school-age children. Med Educ Nutr Culinary. 2017;6(1):18-33.

7. Ikea RD, Prasojo G, Rahmawati I, Maharani. The Effect of Giving a School On Nutritional Status and Anemical Status of Students SDN Pasanggrahan 2 Purwakarta (The Effect of Snack Intervention on Student Nutritional and Anemia Status at Pasanggrahan 2 Elementary School, Purwakarta District), Tanziha, Ecology; 2013. https://doi.org/10.25182/ jgp.2012.7.2.103-110

8. Nora S. The Effect of Supplementary Feeding for School Children on Nutritional Status and Learning Achievement of Elementary School Students in Solok City in 2018. Thesis, Andalas University School of Public Health; 2018.

9. Humaira SA. Organoleptic Properties of Carrot Catfish (Clarias gariepinus) Siomay (Daucus carota L) as a Food Alternative High in Protein, Fiber, and Vitamin A for School Children; 2018.

10. Ratnayani $Y$, Khasanah P, Ditahardiyani MA, Ariani D. Produk mixed food ingredients for toddler nutrition improvement. J PGM. 2010;19(1):21

11. Ministry of Health of the Republic of Indonesia. Table of Intake Fulfillment Category based on Nutrition Adequacy Category. Jakarta: Ministry of Health of the Republic of Indonesia; 1999. 
https://doi.org/10.18311/jeoh/2020/26134

12. Vita TS. Nutritional Status of Class III Children of Sungaililin 1 Public Elementary School; 2015.

13. Lubis Z, Aritonang DE. Nutrition Status and Energy and Protein Adequacy of Private School Children in Namo Gajah Village, Medan Tuntungan District; 2012.

14. Lovita I, Hendrianingtyas M, Triwardhani R. The relationship between resting metabolic rate (RMR) and body composition with HbA1c levels in obesity. Essence Med Sci. 2019;10(1):218-22. https://doi.org/10.15562/ism.v10i1.345

15. Nurapriyanti I. Factors Affecting the Nutritional Status of Toddlers at the White Kunir Posyandu in the Working Area of the Umbulharjo Health Center in Yogyakarta; 2015.

16. Rahmi HG. Analyzing the factors affecting the nutritional status of toddlers in the city of padang based on body weight per height using the cart method. Exact BIR IIm Bid MIPA. 2017;18(2):86-99.

17. Gunners YS, Gunarsa SD. Developmental Psychology of Children and Adolescents; 2010.

18. Yunita T, Suyanto S. Description of Nutritional Status of Elementary School Students in Rangsang Subdistrict, Meranti Islands Regency; 2016.

19. Dian RT, Indah L, Ernalia Y. Description of nutritional status in elementary school students in Bangko district, Rokan Hilir regency. JOM FK. 2016;3(2):1-14

20. SDC Orthodontics, Proffit WR, Fields HW. Age determination of female mandibular pubertal growth spurt based on cervical vertebral maturation indicators. J Educ. 2012;61(1):32, 43-7.

21. Yulni $Y$. The relationship between macronutrient intake and nutritional status in elementary school children in the coastal area of Makassar city in 2013. Indones Public Health Med. 2013;9(4):205-21.

22. Azwar S. Human Attitude Theory and Measurement; 2011.

23. Parinduri MS, Safitri DE. The intake of carbohydrates and protein are related to the nutritional status of school children at Syafana Islamic Primary School, South Tangerang in 2017. ARGIPA. 2018;3(1):48-58. https://doi.org/10.22236/argipa. v3i1.2447

24. Bertalina B. Factors associated with the nutritional status of school-age children (6-12 years). J Primacy. 2013;9(1):5-12.

25. Salawati L, Nurjannah D. The Effect of Protein Intake on The Improvement of Nutritional Status of Children Who Suffering from Acute Respiratory Training Infections;2014.

26. Qamariyah B, Nindya TS. The relationship between energy intake, macro nutrients and total energy expenditure with nutritional status of elementary school children. Correlation between energy intake, macro nutrients, and total energy expenditure and nutritional status of elementary students. Amerta Nutr. 2018;2(1):12-5. https://doi.org/10.20473/amnt. v2i1.2018.59-65

27. R Executive. The Partnership Program for Educational Analysis and Capacity Building (ACDP) Evaluation of the Supplementary Feeding Program for School Children (PMT-AS);2013.
28. UNICEF. Improving Child Nutrition: The achievable imperative for global progress. New York: UNICEF; 2013.

29. Satrianegara MF, Astari AR, Nutrition FKIK UIN Alauddin Makassar. The Effect of Giving Tempe Nugget with Cork Fish Substitution on the Nutritional Status of Elementary School Children in MIS DDI Ainus Syamsi Lette Village, Makassar City, 2014; 2016.

30. IRA, Difference of Nutritional Status of SD Students That Gey PMT-ASI and SD Does Not Get PMT-AS in the Working Area of Puskesmas Air Santokko Pariaman in 2015; 2015.

31. IEP, Suiraoka IP, Sugiani PP. The effect of supplementary feeding for school children on nutritional status of $\mathrm{Hb}$ levels and learning achievement of elementary school children in Denpasar city. Mataram Sangkareang. 2017;3(2355):38-43.

32. Journal Nutrition Health Polytechnic Ministry of Health Aceh and Journal Sukarno Hatta Lampeunerut Aceh Besar. The Effect of Modification of Additional Food on The Nutrition Status of Children (Effect of Supplementary Feeding Modification on Nutritional Status of a Toddler); 2017.

33. Susilowati E. Differences in the Nutritional Status of Elementary School Children Before and After Getting Supplementary Food (PMT) at SDNPlalan I Surakarta City; 2013.

34. Evaluation of the Role of Additional Food Program For Schoo Children (PMT-AS) Toward Nutritional Status, Hemoglobin Levels and Student Learning Achievement (Case Study on SD/MI Students Recipient of PMT-AS in Kalibening District, Banjarnegara Regency in 2010); 2010.

35. Hikmawati L, Kurniawati N, Rostini I, Liviawaty E. Utilization of catfish surimi in making dim sum against the level of favor. J Perikan Kelaut. 2017;8(1):64-72.

36. Nurapriyanti I. Factors Affecting the Nutritional Status of Toddlers at Posyandu Kunir Putih in the Working Area of the Umbulharjo Community Health Center; 2015.

37. Soediaotama AD. Student and Professional Nutrition in Indonesia. Vol. I. Jakarta: Dian Rakyat; 2010

38. Almatsier. Basic Principles of Nutrition, in PT. Jakarta: Gramedia Utama; 2010.

39. Atika W, Punuh M, Kapantov N. The relationship between energy intake and nutritional status of students at SMP Negeri 10 Manado City. Pharmacon. 2015;4(4):303-8.

40. Kurdanti W, Suryani I, Syamsiatun NH, Siwi LP, Adityanti MM, Mustikaningsih D, et al. Factors that influence the incidence of obesity in adolescents. J Nutrition Klin Indones. 2015;11(4):179.

41. Mumpuni YW. How to Deal with Obesity, in Andi, Yogyakarta; 2010.

42. Aprilia DA, Festilia S. The relationship between diet and physical activity on nutritional status in junior high school students, department of nutrition, poltekkes kemenkes pontianak, Indonesia. Pontianak Nutr J. 2018;1(1):10-3.

43. Hartono H. Nutritional Status of Toddlers and Their Interactions Vol. 74. London, United Kingdom: Mediacom Edition; 2016. p. $46-9$.

Author Query???

AQ8: Kindly review the sentence as it seems to be incomplete. 